\title{
Defensive behaviors of Tropidurus catalanensis Gudynas \& Skuk, 1983 (Squamata, Tropiduridae)
}

\section{Thiago Maia-Carneiro*, Simone Langie-Santos and Carlos Arturo Navas}

\author{
${ }^{1}$ Universidade de São Paulo. Departamento de Fisiologia. Laboratório de \\ Ecofisiologia e Fisiologia Evolutiva. Rua do Matão, 321, travessa 14. São Paulo-SP, \\ Brazil (CEP 05508-090). *Email: tmaiacarneiro@gmail.com.
}

\begin{abstract}
Tropidurus catalanensis Gudynas \& Skuk, 1983 (Squamata, Tropiduridae) is a lizard species found in Argentina, Paraguay, Uruguay, and Brazil. Here, we present defensive behaviors performed by $T$. catalanensis, adding information about how these lizards avoid predation. Our observations were in an introduced urban population in the State of São Paulo, Brazil, where individuals performed immobility, locomotor escape by running and climbing, squirreling, tail waving, tail lifting, mouth opening, forced escape, and cloacal discharge. When approached by the potential predator, T. catalanensis tended to stay immobile, but always ran off with further approximation. After locomotor escape, some individuals displayed squirreling - i.e., flight from a side of tree or rock towards the opposite side of it - in order to conceal their presence and difficult visual detection. After flight, a T. catalanensis performed squirreling in a tree and climbed it along the trunk and a limb reaching a height of almost $6 \mathrm{~m}$ from the ground, which might difficult or impede capture by predators coming from below. Other individuals of T. catalanensis also did squirreling climbing up to lower heights on lower trees. When manipulated, a T. catalanensis undulated its tail trying to distract the potential predator in order to escape. Another T. catalanensis lifted its tail, which might also serve as a distraction to predators besides deceiving them by making a lizard look longer and/or bigger. While handled, some T. catalanensis opened their mouths in a threatening display and forced freeing. After capture, T. catalanensis discharged intestinal contents out of their cloaca. Discharges had solid and liquid fractions and repulsive taste and smell. The defensive behaviors reported here are likely advantageous for escaping and increasing chances of survival of lizards.
\end{abstract}

Keywords: Defense behaviors; Defense mechanisms; Defense strategies; Defensive mechanisms; Defensive strategies.
Received

February 10, 2020

Accepted

March 18, 2020

Available on line on

March 25, 2020

Released

April 30, 2020

Full Text Article

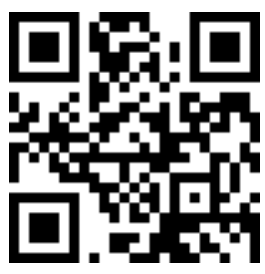

ORCID

(D) $0000-0002-9217-8783$ Thiago Maia-Carneiro

(D) 0000-0002-3290-5838 Simone Langie-Santos

(D) 0000-0002-9859-0568

Carlos Arturo Navas 
Into the Family Tropiduridae lies Tropidurus, one of the lizard genera most widely distributed in South America (Carvalho et al., 2013). Tropidurus catalanensis Gudynas \& Skuk, 1983 lives in Argentina, Paraguay, Uruguay, and Brazil (Kunz and Borges-Martins, 2013; Cacciali and Köhler, 2018). As far as we know, there is no report of this species exhibiting behaviors for defense. Here, we present defensive mechanisms performed by T. catalanensis, adding information about how such lizards avoid predation. Our observations were in an introduced urban population on February 10, 2018 between 09:30 $\mathrm{h}$ and 16:30 $\mathrm{h}$ in the Municipality of Osasco $\left(23.5423^{\circ} \mathrm{S}, 46.7602^{\circ} \mathrm{W}\right)$, State of São Paulo, Brazil, where individuals performed the following defensive behaviors: immobility; locomotor escape by running and climbing; squirreling; tail waving; tail lifting; mouth opening; forced escape; cloacal discharge.

When approached by the potential predator (TMC), T. catalanensis tended to stay immobile to prevent detection due to motion (Greene, 1988). When the risk of staying motionless was supposedly too high (Ydenberg and Dill, 1986; Cooper and Frederick, 2007), lizards always ran off. After locomotor escape, some individuals displayed squirreling - i.e., flight from a side of tree or rock towards the opposite side of it. By squirreling, T. catalanensis conceal their presence and difficult visual detection, as also do T. hispidus and T. semitaeniatus (Maia-Carneiro and Rocha, 2015) and other more distantly relative lizard species (Greene, 1988; Regalado, 1998; Smith and Lemos-Espinhal, 2005). After flight, a T. catalanensis performed squirreling in a tree and climbed it along the trunk and a limb reaching a height of almost $6 \mathrm{~m}$ from the ground, which might difficult or impede capture by predators coming from below. Other individuals of $T$. catalanensis also did squirreling climbing up to lower heights on lower trees.

When manipulated, a $T$. catalanensis undulated its tail trying to distract the potential predator in order to escape. Tail waving is reported for other lizard species (Rocha, 1993; Alonso et al., 2010), including tropidurids (Galdino et al., 2006; Machado, 2007; Nunes, 2012). As other tropidurid lizards also (Galdino et al., 2006), a T. catalanensis lifted its tail, which might likewise serve as a distraction to predators besides deceiving them by making a lizard look longer and/or bigger. While handled, some T. catalanensis opened their mouths in a threatening display and forced freeing (see Machado et al., 2007; Nunes et al., 2012), which might make predators hesitate and favor lizards' escaping. After capture, T. catalanensis discharged intestinal contents out of their cloaca. Discharges had solid and liquid fractions and repulsive smell and taste. The movements of lizards launched discharges and made it possible to experience the taste (unpleasantly). Cloacal discharge occurs in different lizard species, including tropidurids (Eurolophosaurus nanuzae - Galdino et al., 2006; T. montanus - Machado et al., 2007; T. itambere - Nunes et al., 2012; T. hispidus and T. semitaeniatus - Maia-Carneiro and Rocha, in press). The defensive behaviors reported here are likely advantageous for escaping and increasing chances of survival of lizards.

\section{Acknowledgements}

We are grateful to the Coordenação de Aperfeiçoamento de Pessoal de Nível Superior (CAPES) and the Fundação de Amparo à Pesquisa do Estado de São Paulo (FAPESP; São Paulo Research Foundation) for grant to TMC and for financing the research (process no. 2016/23599-3).

\section{Conflicts of interest}

Authors declare that they have no conflict of interests. 


\section{References}

Alonso, M. L. B.; Cotrina, J. M.; Pardo, D. A.; Font, E.; Molina-Borja, M. J. Sex differences in antipredator tail-waving displays of the diurnal yellow-headed gecko Gonatodes albogularis from tropical forests of Colombia. Journal of Ethology, v. 28, p. 305-311, 2010. https://doi.org/10.1007/s10164-009-0186-4

Cacciali, P.; Köhler, G. Diversity of Tropidurus (Squamata: Tropiduridae) in Paraguay: An integrative taxonomic approach based on morphological and molecular genetic evidence. Zootaxa, v. 4375, no. 4, p. 511-536, 2018. https://doi.org/10.11646/zootaxa.4375.4.3

Carvalho, A. L. G.; Britto, M. R.; Fernandes, D. S. Biogeography of the lizard genus Topidurus Wied-Neuwied, 1825 (Squamata: Tropiduridae): Distribution, endemism, and area relationships in South America. PLoS ONE, v. 8, no. 3, e59736, 2013. https://doi.org/10.1371/journal.pone.0059736

Cooper, W. E.; Frederick, W. G. Optimal flight initiation distance. Journal of Theoretical Biology, v. 244, no. 1, p. 59-67, 2007. https://doi.org/10.1016/j.jtbi.2006.07.011

Galdino, C. A. B.; Pereira, E. G.; Fontes, A. F.; Van Sluys, M. Defense behavior and tail loss in the endemic lizard Eurolophosaurus nanuzae (Squamata, Tropiduridae) from Southeastern Brazil. Phyllomedusa, v. 5, no. 1, p. 25-30, 2006. https://doi.org/10.11606/issn.23169079.v5i1p25-30

Greene, H. W. Anti-predator mechanisms in reptiles. In: Gans, C.; Huey, R. B. (Eds.). Biology of the Reptilia, 16. New York: Allan R. Liss, 1988. p. 1-152.

Kunz, T. S.; Borges-Martins, M. A new microendemic species of Tropidurus (Squamata: Tropiduridae) from Southern Brazil and revalidation of Tropidurus catalanensis Gudynas \& Skuk, 1983. Zootaxa, v. 3681, p. 413-439, 2013. https://doi.org/10.11646/ zootaxa.3681.4.6

Machado, L. L.; Galdino, C. A. B.; Sousa, B. M. Defensive behavior of the lizard Tropidurus montanus (Tropiduridae): Effects of sex, body size and social context. South American Journal of Herpetology, v. 2, no. 2, p. 136-140, 2007. https://doi.org/10.2994/18089798(2007)2[136:DBOTLT]2.0.C0;2

Maia-Carneiro, T.; Rocha, C. F. D. Tropidurus hispidus (Lagartixa; Peters' Lava Lizard) and Tropidurus semitaeniatus (Calango-de-Lagedo). Cloacal discharge. Herpetological Review, in press.

Maia-Carneiro, T; Rocha, C. F. D. Flight initiation distances of Tropidurus hispidus and Tropidurus semitaeniatus (Squamata, Tropiduridae) in sympatry. Herpetological Conservation and Biology, v. 10, no. 2, p. 661-665, 2015.

Nunes, J. V.; Elisei, T.; Sousa, B. M. Anti-predator behaviour in the Brazilian lizard Tropidurus itambere (Tropiduridae) on a rocky outcrop. Herpetological Bulletin, v. 120, p. 22-28, 2012.

Regalado, R. Approach distance and escape behavior of three species of Cuban Anolis (Squamata, Polychrotidae). Caribbean Journal of Science, v. 34, p. 211-217, 1998.

Rocha, C. F. D. The set of defence mechanisms in a tropical sand lizard (Liolaemus lutzae) of Southeastern Brazil. Ciência e Cultura, v. 45, no. 2, p. 116-122, 1993.

Smith, G. R.; Lemos-Espinal, J. A. Comparative escape behavior of four species of Mexican phrynosomatid lizards. Herpetologica, v. 61, no. 3, p. 225-232, 2005.

Braz. J. Biol. Sci., 2020, Vol. 7, No. 15, p. 39-42. 
Ydenberg, R. C.; Dill, L. M. The economics of fleeing from predators. Advances in the Study of Behavior, $\quad$ v. 16 , p. 229-249, 1986. https://doi.org/10.1016/S00653454(08)60192-8

CC License information: This is an open-access article distributed under the terms of the Creative Commons original work is properly cited. 